\title{
PENAMBAHAN EKTRAK KULIT BUAH NAGA KE DALAM PENGENCER TRIS KUNING TELUR UNTUK MENINGKATKAN KUALITAS SEMEN BEKU KAMBING PERANAKAN ETTAWA
}

\author{
Bowo SisWANDOKO ${ }^{1}$, Siti ZAENAB ${ }^{1}$, HuSAMAH ${ }^{1,2}$
}

\author{
${ }^{1}$ Program Studi Pendidikan Biologi, Fakultas Keguruan dan Ilmu Pendidikan, Universitas Muhammadiyah Malang, Jawa Timur \\ ${ }^{2}$ Pusat Studi Lingkungan dan Kependudukan, Universitas Muhammadiyah Malang, Jawa Timur
}

\section{A B S T RACT}

The success of artificial insemination is determined by the quality of the frozen semen used. Free radicals and cold shock may reduce the quality of frozen semen. These can be prevented or reduced by the addition of antioxidants. Dragon fruit skin extract is rich in natural antioxidants. This study is aimed to analyze the effect of the addition of dragon fruit skin extract on quality (motility, viability, and abnormality) of frozen goat semen. The most effective concentration in frozen semen. The true experimental research was used with the posttest-only control group design. Data analysis was done by using One Way ANOVA followed by Duncan's test of $0.5 \%$ assisted by SPSS 22. The research was conducted in May-June 2017 at BBIB Singosari, Malang. The result showed that $0.50 \%$ concentration gave the highest motility $(26.00 \pm 6.51 \%)$ and the lowest abnormality $(5.6 \pm 2.7 \%)$, while at $0.75 \%$ gave the highest viability $(61.60 \pm 8.11 \%)$. It can be concluded that there is a significant effect $(\mathrm{p}<0.05)$ addition of dragon fruit's rind extract to the frozen semen quality (motility, viability, and abnormality) of ettawa goat and the most effective extract concentration varies on each quality parameter.

KEY WORDS: PE goat, frozen semen, motility, viability and abnormality

Penulis korespondensi: Bowo SiswANDoKo | email: bowosiswandoko9@gmail.com Dikirim: 10-09-2017 | Diterima: 01-11-2017

\section{PENDAHULUAN}

Upaya yang dapat dilakukan dalam mempertahankan mutu genetik ternak termasuk kambing peranakan ettawa (PE) adalah dengan melakukan Inseminasi Buatan (IB). Inseminasi Buatan merupakan rekayasa teknik mengawinkan ternak secara buatan dengan mendeposisiskan semen yang telah diencerkan dengan pengencer tertentu ke dalam saluran reproduksi betina (Tophianong, 2014). Keberhasilan IB dipengaruhi oleh empat faktor yang saling berhubungan satu sama lain, yaitu pemilihan sapi akseptor, kualitas semen, ketepatan deteksi birahi, dan keterampilan inseminator (Badan Standarisasi Nasional, 2008).

Capaian kebuntingan indukan kambing PE dari hasil IB masih rendah di wilayah pantai dan pegunungan yaitu $37,5 \%$ dan 40,0\% (Utomo, 2013). Keberhasilan kebuntingan dari hasil IB dapat dilakukan dengan memperbaiki kualitas semen beku. Kualitas semen dipertahankan dengan melakukan proses pengenceran. Syarat bahan pengencer yang digunakan yaitu tidak mengandung zat beracun bagi spermatozoa, mengandung nutrisi bagi hidup spermatozoa selama proses penyimpanan, dapat mempertahankan $\mathrm{pH}$ semen dan dapat melindungi spermatozoa dari cold shock, menghambat atau mengurangi reaksi peroksidasi lipid akibat aktivitas radikal bebas serta menambah volume semen (Feradis, 2009; Susilawati, 2013).

Pengencer yang sering digunakan adalah tris kuning telur, yang komposisinya terdiri atas Tris aminomethan, asam sitrat, laktosa, fruktosa, raffinosa, kuning telur, penisilin, streptomycin dan aquabides (Ditjennak, 2000). Bahan yang bisa ditambahkan untuk pengencer semen adalah antioksidan.
Penambahan antioksidan pada pengencer dapat dirasakan manfaatnya dalam meningkatkan kualitas semen beku (Feradis, 2010). Pemberian antioksidan dengan dosis yang tepat memberikan hasil maksimal untuk mencegah dan mengurangi reaksi peroksida lipid akibat aktivitas radikal bebas pada membran plasma spermatozoa, dimana bagian tersebut kaya akan asam lemak tak jenuh sehingga rentan terhadap reaksi peroksida lipid (Bebas et al., 2016). Antioksidan dapat diperoleh dari sumber alami seperti buah (Sayuti \& Rina, 2015). Salah satunya buah naga (Hylocereus polirhizus).

Buah naga memiliki kandungan flavonoid. Flavonoid merupakan salah satu senyawa antioksidan yang berfungsi mengatasi atau menetralisir radikal bebas (Fitri et al., 2016). Penelitian sebelumnya penambahan ektrak buah naga $0,25 \%$ pada pengencer CEP-1 mampu mempertahankan motilitas, viabilitas, dan abnormalitas spermatozoa peranakan kambing boer pada suhu $5^{\circ} \mathrm{C}$ (Munawarah, 2014). Penambahan ekstrak buah naga pada pengencer cauda epididymal plasma (CEP-1) sebesar $0,75 \%$ juga mampu mempertahankan motilitas dan viabilitas spermatozoa kambing boer pada penyimpanan suhu $32^{\circ} \mathrm{C}$ selama 12 jam (Imansih, 2014).

Antioksidan banyak terkandung pada bagian kulit buah naga, bagian yang umumnya tidak termanfaatkan oleh masyarakat. Ekstrak kulit buah naga banyak mengandung antioksidan jenis antosianin (Noor et al., 2016). Pigmen antosianin yang tergolong flavonoid dapat berfungsi sebagai aktioksidan atau menangkal radikal bebas (Wulandari, 2016). Setiap $1 \mathrm{mg} / \mathrm{ml}$ kulit buah naga merah mampu menghambat radikal bebas sebesar $83,48 \pm 5,03 \%$ (Nurliya et al., 2010). Kandungan ekstrak kulit buah naga secara teoritis mampu 
mencegah dan mengurangi kerusakan spermatozoa akibat pengaruh radikal bebas dan cold shock penyebab penurunan kualitas semen beku kambing PE.

Berdasarkan berbagai uaraian tersebut penelitian ini bertujuan untuk menganalisis pengaruh penambahan ekstrak kulit buah naga terhadap kualitas (motilitas, viabilitas dan abnormalitas) semen beku kambing PE dan menentukan konsentrasi paling efektif terhadap kualitas semen beku. Penelitian ini diharapkan mampu memberikan informasi kepada masyarakat peternak dan inseminator tentang manfaat ekstrak kulit buah naga sebagai bahan tambahan pengencer semen untuk meningkatkan kualitas semen beku kambing PE.

\section{MET ODE}

Penelitian ini adalah True Experiment Research dengan menggunakan pos-test dengan kelompok kontrol (The Posttest-Only Control Group Design). Pembuatan ekstrak kulit buah naga (Hylocereus polyrhizus) terstandarisasi dilakukan di UPT Metaria Medica, Jl. Lahor No. 87 Kota Batu Jawa Timur. Pengujian kualitas semen beku dilakukan di Laboratorium Balai Besar Inseminasi Buatan (BBIB) Singosari, Desa Toyomarto, Kecamatan Singosari-Malang, Jawa Timur. Penelitian ini dilaksanakan pada tanggal 8 Mei23 Juni 2017.

Populasi dalam penelitian ini adalah seluruh semen pejantan kambing PE yang ada di BBIB Singosari. Sampel yang digunakan adalah semen dari pejantan kambing PE dengan usia \pm 3 tahun, dengan kriteria motilitas individu rendah yaitu 40-55\%; warna putih bening sampai putih kekuningan; pH 6-8; konsistensi sedang-pekat; volume 0,81,2; konsentrasi 2.000-3.000 jt sel/ml; dan motilitas masa $2+-3+($ Kusumawati et al., 2016). Bahan berupa semen segar kambing PE yang digunakan penelitian ini telah memenuhi standar tersebut sebagaimana pada Tabel 1 .

Tabel 1. Karakteristik Semen Segar Kambing PE yang Digunakan untuk Penelitian

\begin{tabular}{ll}
\hline Parameter & Nilai Rerata \\
\hline Warna & Putih Kekuningan (PK) \\
pH & 6,64 \\
Konsistensi & Pekat \\
Volume (ml) & 1,56 \\
Konsentrasi (jt/ml) & 2.587 \\
Motilitas masa & $2+-3+$ \\
Motilitas individu (\%) & 43 \\
\hline
\end{tabular}

Teknik pengambilan sampel adalah simple random sampling. Buah Naga yang digunakan buah naga merah yang dibudidayakan di Kabupaten Banyuwangi, Jawa Timur. Variabel bebas dalam hal ini adalah ekstrak kulit buah naga yaitu konsentrasi $0,25 \% ; 0,50 \% ; 0,75 \%$; dan $1,00 \%$ yang menurut teori diyakini mengandung antosianin sebesar $58,0720 \pm 0,0001 \mathrm{mg} / \mathrm{L}$ (Putri et al., 2015). Variabel terikat penelitian adalah peningkatan kualitas semen dengan parameter motilitas, viabilitas, dan abnormalitas. Variabel kontrol penelitian adalah pejantan kambing PE yang berumur \pm 3 tahun, yang diberi pakan hijauan, legum, dan konsentrat. Pengambilan semen dilakukan dua kali seminggu menggunakan vagina buatan. Pengencer yang digunakan adalah tris kuning telur dengan kandungan gliserol 6,5\% pada volume total. Komposisi pengencer tris kuning telur yang digunakan meliputi tris aminomethane, asam sitrat monohidrat, lactose dan rafinose, kuning telur, penisilin, strepromycin dan aquabidestilata.

Alat yang digunakan dalam penelitian ini meliputi evaporator, waterbath, vagina buatan, mikroskop, spektrofotometer, cool top, mikropipet, digit cool, dan countainer storage. Prosedur penelitian diawali dengan membuat ekstrak kulit buah naga lalu menambahkan ekstrak ke dalam pengencer tris kuning telur sesuai dengan konsentrasi perlakuan. Selanjutnya dilakukan penampungan semen segar dan dievaluasi kualitasnya meliputi volume, warna, $\mathrm{pH}$, konsentrasi, motilitas masa, dan motilitas individu. Tahapan selanjutnya adalah pengenceran yang meliputi pengenceran $\mathrm{A} 1$ (suhu $38^{\circ} \mathrm{C}$ ), $\mathrm{A} 2$ (suhu $5^{\circ} \mathrm{C}$ ), dan $\mathrm{B}$ (suhu $5^{\circ} \mathrm{C}$ dan penambahan gliserol), lalu dilakukan evaluasi pasca pengenceran (before freezing). Tahapan selanjutnya dilakukan pengisian dan penyegelan kemudian semen yang sudah terkemas dalam wadah (straw) berkapasitas volume $0,25 \mathrm{ml}$ dengan total sel spermatozoa 50 jt. Secara berturut-turut masuk tahapan pra pembekuan (pre freezing) dimana semen akan diturunkan suhunya dari $5^{\circ} \mathrm{C}$ sampai $-140^{\circ} \mathrm{C}$ dengan durasi waktu 7 menit, dilanjutkan tahap pembekuan dengan merendam semen kedalam $\mathrm{N}_{2}$ cair bersuhu $-196^{\circ} \mathrm{C}$ selama 24 jam (freezing), pencairan kembali (thawing) dilakukan dengan memasukkan semen beku kedalam Water Bath yang berisi air hangat bersuhu $38^{\circ} \mathrm{C}$ selama $15-30$ detik, dan evaluasi pasca thawing. Variabel yang diamati adalalah motilitas, viabilitas, dan abnormalitas.

Prosedur uji motilitas atau pergerakan spermatozoa menggunakan mikroskop binokuler dengan perbesaran $40 \mathrm{x}$ 10 pada bidang object glass kemudian ditetesi semen ditutup cover glass. Pengujian viabilitas dilakukan dengan membuat preparat ulas menggunakan pewarna eosin. Prosedur uji viabilitas atau hidup-mati spermatozoa menggunakan mikroskop binokuler dengan perbesaran $40 \mathrm{x}$ 10 dengan mengihitung spermatozoa sebanyak 100-200 sel dalam waktu maksimal 30 detik. Pengujian abnormalitas seperti uji viabilitas yaitu dilakukan dengan membuat preparat ulas menggunakan pewarna eosin. Prosedur uji abnormalitas spermatozoa menggunakan mikroskop binokuler dengan perbesaran $40 \times 10$ dengan mengihitung spermatozoa sebanyak 100-200 sel. Abnormalitas semen dianggap normal apabila spermatozoa yang abnormal jumlahnya tidak lebih dari $20 \%$ dari total semen yang dihitung.

Data yang diperoleh ditabulasi dan dianalisis menggunakan One Way Anova dilanjutkan dengan uji Duncan's 0,5\% menggunakan software SPSS 22.

\section{HASIL DAN PEMBAHASAN}

Rerata hasil uji motilitas individu spermatozoa ditunjukan pada Tabel 2. Hasil analisis ragam menunjukan bahwa perlakuan konsentrasi 0,50\% penambahan ekstrak kulit buah naga dalam pengencer dapat menghasilkan rerata motilitas individu spermatozoa yang paling tinggi pasca pengenceran yaitu $41 \pm 4,18 \%$. Sementara pada pemeriksaan pasca thawing perlakuan konsentrasi 0,50\% penambahan ekstrak kulit buah naga dalam pengencer mampu menghasilkan rerata motilitas tertinggi yaitu sebesar $26 \pm 6,51 \%$. Nilai jauh lebih tinggi dibandingkan perlakuan kontrol yang hanya bisa mempertahankan motilitas spermatozoa pasca pengenceran sebesar $31 \pm 4,18 \%$ dan pasca thawing sebesar $15 \pm 5 \%$. 
Tabel 2. Rerata \pm SD persentase motilitas individu spermatozoa ejakulat kambing peranakan ettawa (Carpa hircus) sebelum dan pasca penyimpanan dalam berbagai konsentrasi ekstrak kulit buah naga dalam pengencer triskuning telur (\%)

\begin{tabular}{lll}
\hline Perlakuan & $\begin{array}{l}\text { Semen Cair } \\
\text { (Before Freezing) }\end{array}$ & $\begin{array}{l}\text { Semen Beku } \\
\text { (Pasca Thawing) }\end{array}$ \\
\hline Kontrol & $31 \pm 4,18^{\mathrm{a}}$ & $15 \pm 5^{\mathrm{a}}$ \\
$0.25 \%$ & $38 \pm 2,73^{\mathrm{b}}$ & $25 \pm 7,07^{\mathrm{ab}}$ \\
$0.50 \%$ & $41 \pm 4,18^{\mathrm{c}}$ & $26 \pm 6,51^{\mathrm{b}}$ \\
$0.75 \%$ & $38 \pm 5,7^{\mathrm{b}}$ & $26 \pm 9,61^{\mathrm{ab}}$ \\
$1.00 \%$ & $36 \pm 5,47^{\mathrm{a}}$ & $23 \pm 10,36^{\mathrm{ab}}$ \\
\hline
\end{tabular}

Keterangan: Huruf superskrip yang berbeda pada kolom yang sama menunjukkan adanya perbedaan yang nyata $(\mathrm{P}<0,05)$ antar perlakuan.

Adanya penurunan motilitas dari pemeriksaan pasca pengenceran ke pemeriksaan pasca thawing. Secara umum faktor-faktor yang mempengaruhi motilitas sperma adalah metode penampungan semen, lingkungan, penanganan dan perawatan semen sesudah penampungan, interval antara penampungan dan evaluasi semen, variasi pejantan serta variasi musim (Kostama \& Sutama, 2004). Namun berdasarkan penelitian penurunan motilitas dimungkinkan terjadi akibat kegiatan processing dari semen cair diubah menjadi semen beku sehingga terjadi perubahan suhu yang ekstrim dari $5^{\circ} \mathrm{C}$ ke $196^{\circ} \mathrm{C}$. Motilitas spermatozoa dipengaruhi oleh suhu lingkungan dan persentase spermatozoa hidup yang normal. Selama proses penyimpanan akan terjadi penurunan temperatur, sehingga akan timbul toksik pada seminal plasma dan tekanan osmotik (Husin et al., 2007).

Hasil rerata statistik menunjukkan bahwa dengan penambahan ekstrak kulit buah naga didapatkan nilai motilitas dari tertinggi sampai terendah berturutturut pada pemeriksaan pasca thawing yaitu perlakuan $\quad 0,50 \% ; \quad 0,75 \% ; \quad 0,25 \% ; \quad 1,00 \%$ dan perlakuan kontrol. Hasil tersebut membuktikan bahwa kandungan antioksidan pada ekstrak kulit buah naga mampu menekan penurunan motilitas spermatoza kambing PE, walau konsentrasi yang diujikan tidak linear.

Berdasarkan uraian diatas maka dapat diketahui bahwa dengan penambahan ekstrak kulit buah naga ke dalam medium pengawet tris kuning telur dan gliserol memberikan nilai motilitas individu lebih baik dibandingkan tanpa penambahan ekstrak kulit buah naga. Kandungan antioksidan pada ekstrak buah naga mampu mempertahankan motilitas lebih baik dibandingkan tanpa penambahan ekstrak kulit buah naga (Imansih, 2014). Penambahan ekstrak buah naga pada pengencer CEP-1 mampu memberikan motilitas lebih tinggi serta meningkatkan gerak progesif spermatozoa (Munawaroh, 2014). Sehingga penambahan antioksidan berperan penting menghambat reaksi peroksida lipid yang mampu merusak membran spermatozoa akibat penyimpanan. Membran plasma spermatozoa kaya akan asam lemak tak jenuh dan oleh karena itu rentan terhadap kerusakan peroksidasi (Rizal \& Herdis, 2010).
Antioksidan juga berperan mencegah kerusakan membran plasma spermatozoa yang disebabkan cekaman dingin (cold shock) dan memberikan perlindungan terhadap perubahan yang disebabkan pembekuan (Feradis, 2010).

Hasil pengamatan mikrograf uji viabilitas spermatozoa memperlihatkan spermatozoa yang tidak menyerap warna eosin ditunjukan pada huruf A sedangkan huruf B memperlihatkan spermatozoa yang menyerap larutan eosin, seperti ditunjukkan pada Gambar 1. Rerata hasil uji viabilitas individu spermatozoa sebelum dan sesudah penyimpanan dalam medium ditunjukkan pada Tabel 3.

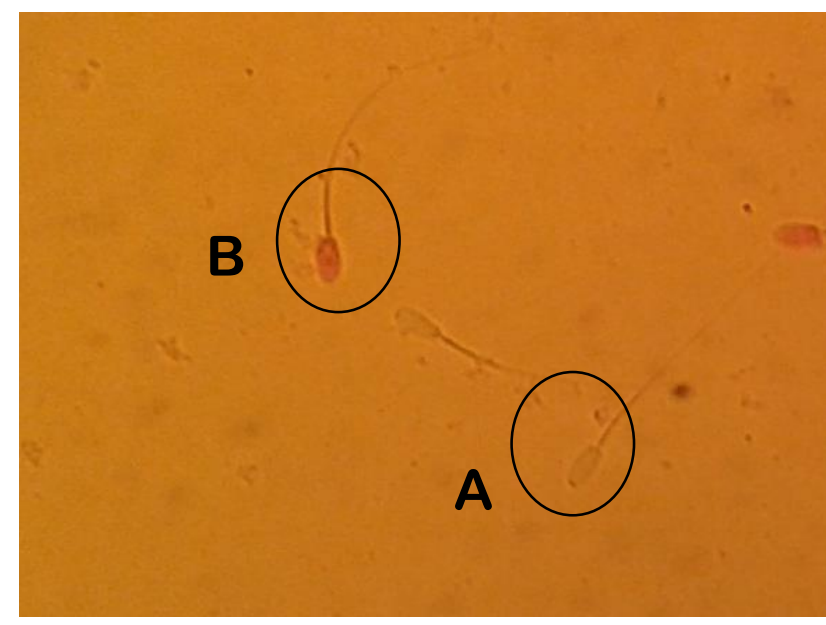

Gambar 1. Gambar pengamatan hasil uji viabilitas. A: Spermatozoon hidup, B: Spermatozoon mati

Tabel 3. Rerata \pm SD persentase vabilitas spermatozoa ejakulat kambing peranakan ettawa (Carpa hircus) sebelum dan pasca penyimpanan dalam berbagai konsentrasi ekstrak kulit buah naga dalam pengencer tris-kuning telur (\%)

\begin{tabular}{lll}
\hline Perlakuan & $\begin{array}{l}\text { Semen Cair } \\
\text { (Before Freezing) }\end{array}$ & $\begin{array}{l}\text { Semen Beku } \\
\text { (Pasca Thawing) }\end{array}$ \\
\hline Kontrol & $52,4 \pm 1,81^{\mathrm{a}}$ & $46,4 \pm 3,36^{\mathrm{a}}$ \\
$0.25 \%$ & $61 \pm 13,03^{\mathrm{ab}}$ & $59,4 \pm 6,06^{\mathrm{bc}}$ \\
$0.50 \%$ & $65,6 \pm 11,32^{\mathrm{bc}}$ & $56,6 \pm 3,2^{\mathrm{bc}}$ \\
$0.75 \%$ & $73 \pm 6,2^{\mathrm{bc}}$ & $61,6 \pm 8,11^{\mathrm{c}}$ \\
$1.00 \%$ & $74,6 \pm 6,61^{\mathrm{c}}$ & $52 \pm 6,96^{\mathrm{ab}}$ \\
\hline
\end{tabular}

Keterangan: Huruf superskrip yang berbeda pada kolom yang sama menunjukkan adanya perbedaan yang nyata $(\mathrm{P}<0,05)$ antar perlakuan.

Hasil rerata analisis ragam persentase viabilitas spermatozoa menunjukan bahwa perlakuan 1,00\% ekstrak kulit buah naga kedalam pengencer tris kuning telur mampu memberikan nilai viabilitas spermatozoa tertinggi pasca pengenceran yaitu sebesar 74,6 $\pm 6,61 \%$ dibandingkan perlakuan kontrol yaitu $52,4 \pm 1,81 \%$ dan semen beku hasil pemeriksaan viabilitas pasca thawing tertinggi terdapat pada konsentrasi $0,75 \%$ penambahan ekstrak kulit buah naga pada pengencer tris kuning telur yaitu sebesar $61,6 \pm 8,11 \%$ berbeda nyata dibandingkan perlakuan kontrol yaitu sebesar $46,4 \pm 3,36 \%$, sebagaimana telah disajikan pada Tabel 3 .

Hasil rerata statistik menunjukan bahwa dengan penambahan ekstrak kulit buah naga didapatkan nilai viabilitas dari tertinggi sampai terendah berturut- 
turut pada pemeriksaan pasca thawing yaitu perlakuan $0,75 \% ; 0,25 \% ; 0,50 \% ; 1,00 \%$; dan kontrol. Data motilitas tidak linier dengan data viabilitas spermatozoa kambing PE pasca perlakuan penambahan ekstrak buah naga hasil penelitian ini. Hasil tersebut membuktikan bahwa penambahan ekstrak kulit buah naga pada medium penyimpanan mampu memberikan efek positif bagi daya hidup spermatozoa. Hasil ini mengkonfirmasi laporan sebelumnya bahwa penambahan ekstrak buah naga sebesar $0,75 \%$ pada pengencer CEP-1 mampu meningkatkan angka viabilitas semen cair pasca pengenceran kambing boer (Imansih, 2014). Kandungan antioksidan pada ekstrak kulit buah naga diargumentasikan mampu mencegah dan mengurangi peroksida lipid akibat radikal bebas sehingga mampu menekan efek peroksidasi pada spermatozoa yang dapat menyebabkan penghambatan fruktolisis dan respirasi, pengikatan enzim intraseluler dan kerusakan struktur membran plasma terutama pada bagian akrosom dan mampu mempertahankan viabilitas semen beku (Herdis et al., 2008).

Hasil pengamatan uji abnormalitas spermatozoa menunjukkan berbagai bentuk abnormalitas sekunder baik di bagian kepala maupun ekor, sebagaimana dapat dilihat pada Gambar 2. Hasil pengamatan dan perhitungan rerata hasil uji abnormalitas individu spermatozoa ditunjukkan pada Tabel 4. Secara umum abnormalitas pada semen kambing PE yang ditemukan adalah abnormalitas sekunder seperti ekor bergelung, ekor patah dan ekor terputus dari kepala. Sementara abnormalitas primer yang ditemukan adalah kepala lebih kecil dari ukuran normal.

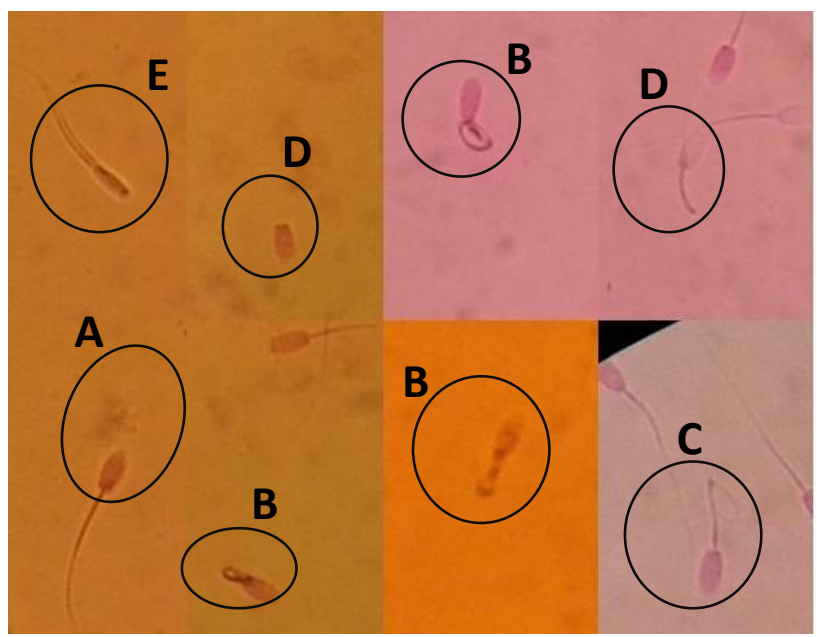

Gambar 2. Gambar pengamatan hasil uji abnormalitas. A: Spermatozoa normal, B: Ekor bergelung, C: Ekor patah, D: Ekor terputus, E: Kepala kecil

Berdasarkan Tabel 4, hasil analisis ragam data abnormalitas spermatozoa menunjukan bahwa perlakuan ekstrak kulit buah naga 0,50\% ke dalam pengencer tris kuning telur mampu memberikan nilai abnormalitas sepermatozoa pasca pengencerean paling rendah yaitu sebesar 6,40 $\pm 2,07$ dibandingan perlakuan kontrol yaitu sebesar 12,40 $\pm 1,51$.
Sementara pemeriksaan pasca thawing nilai abnormalitas terendah terdapat pada perlakuan $0,50 \%$ yaitu $5,60 \pm 2,7 \%$ dan perlakuan $1,00 \%$ sebesar 5,6 $\pm 3,28 \%$. Hasil tersebut lebih rendah jika dibandingkan pada perlakuan kontrol yaitu sebesar $12,10 \pm 1,67 \%$.

Tabel 4 Rerata \pm SD persentase abnormalitas spermatozoa ejakulat kambing peranakan ettawa (Carpa hircus) sebelum dan pasca penyimpanan dalam berbagai konsentrasi ekstrak

kulit buah naga dalam pengencer tris-kuning telur (\%)

\begin{tabular}{lll}
\hline Perlakuan & $\begin{array}{l}\text { Semen Cair } \\
\text { (Before Freezing) }\end{array}$ & $\begin{array}{l}\text { Semen Beku } \\
\text { (Pasca Thawing) }\end{array}$ \\
\hline Kontrol & $12,40 \pm 1,51^{\mathrm{b}}$ & $12,10 \pm 1,67^{\mathrm{b}}$ \\
$0.25 \%$ & $6,80 \pm 1,64^{\mathrm{a}}$ & $6,00 \pm 2,34^{\mathrm{a}}$ \\
$0.50 \%$ & $6,40 \pm 2,07^{\mathrm{a}}$ & $5,60 \pm 2,70^{\mathrm{a}}$ \\
$0.75 \%$ & $7,40 \pm 2,96^{\mathrm{a}}$ & $5,80 \pm 2,77^{\mathrm{a}}$ \\
$1.00 \%$ & $8,80 \pm 3,03^{\mathrm{a}}$ & $5,60 \pm 3,28^{\mathrm{a}}$ \\
\hline
\end{tabular}

Keterangan: Huruf superskrip yang berbeda pada kolom yang sama menunjukkan adanya perbedaan yang nyata $(\mathrm{P}<0,05)$ antar perlakuan.

Hasil rerata statistik menunjukan bahwa dengan penambahan ekstrak kulit buah naga didapatkan nilai abnormalitas dari terendah sampai tertinggi berturutturut pada pemeriksaan pasca thawing yaitu 0,50\%; 1,00\%; 0,75\%; 0,25\%; dan kontrol. Hasil tersebut membuktikan bahwa penambahan ekstrak kulit buah naga pada pengencer mampu menekan angka abnormalitas semen beku kambing PE, dikarenakan kandungan senyawa antioksidan pada ekstrak kulit buah naga mampu melindungi spermatozoa dari cold shock. Persentase abnormalitas meningkat dipengaruhi oleh temperatur dan keseimbangan tekanan osmotik dari proses metabolik yang berlangsung terus menerus selama penyimpanan (Husin et al., 2007). Secara umum hasil pemeriksaan rerata abnormalitas dari lima perlakuan tergolong baik karena abnormalitas spermatozoa tidak mencapai angka lebih dari 20\%, meskipun berasal dari semen dengan motilitas rendah. Persentase abnormalitas spermatozoa sangat penting untuk diketahui karena abnormalitas yang tinggi hingga $20 \%$ dari jumlah spermatozoa akan menganggu fertilitas pejantan secara umum (Hidayati et al., 2015).

\section{K E S I M P U L A N}

Penambahan ekstrak kulit buah naga pada pengencer tris kuning telur berpengaruh signifikan untuk meningkatkan kualitas semen beku kambing PE. Penambahan konsentrasi ekstrak kulit buah naga $0,50 \%$ kedalam medium penyimpanan tris kuning telur bergliserol, merupakan konsentrasi paling efektif untuk meningkatkan kualitas semen beku kambing PE ditinjau dari motilitas, viabilitas, dan abnormalitas. Pada pemberian konsentrasi ekstrak kulit buah naga $0,75 \%$ kedalam pengencer tris kuning telur mampu memberikan angka viabilitas paling efektif pada pemeriksaan pasca thawing. Penambahan ekstrak yang paling efektif berbeda-beda pada setiap parameter kualitas, baik motilitas, viabilitas, maupun abnormalitas. 


\section{DAFT AR REFERENSI}

Badan Standarisasi Nasional. 2008. Standar Nasional Indonesia (SNI). SNI. 4869.1-2008. Semen Beku Sapi. Jakarta:Badan Standar Nasional. [Internet]. Available from http:// bbibsingosari. com/ images/ sni\% 204869.1-2008 \%20semen \%20beku, \%20bagian \%201 \%20sapi.pdf

Bebas W, Geovany LB, Made KB. 2016. Penambahan Vitamin E Pada Pengencer BTS Terhadap Daya Hidup Dan Motilitas Spermatozoa Babi Landrace Pada Penyumpanan $15^{\circ} \mathrm{C}$. Buletin Veteriner Udayana. 8(1):1-7.

Direktorat Jendral Peternakan. 2000. Prosedur Tetap (PROTAP) Produksi Dan Distribusi Semen Beku. Jakarta: Departemen Pertanian Direktorat Jendral Produksi Peternakan. [Internet]. Available from: http://lib. bppsdmp. pertanian. go.id/ ucs/ index.php? $\mathrm{p}=$ show_detail\&id $=1790$

Feradis. 2010. Bioteknologi Reproduksi Pada Ternak. Bandung: Alfabeta; p.59-60

Feradis. 2009. Peranan Antioksidan Dalam Pembekuan Semen. Jurnal Peternakan. 6(2):63-70

Fitri NL, Susetyarini RE, Waluyo Lud. 2016. The Effect Of Ciplukan (Physalis angulata L.) Fruit Extract On SGPT and SGOT Levels Against White Male Mice (Mus musculus) Hyperglycemia Induced By Alloxan As Biology Learning Resources. Jurnal Pendidikan Biologi Indonesia. 2(2):180-187.

Herdis M, Surachman, Yulnawati, Rizal M, Maheshwari H. 2008. Viabilitas Dan Keutuhan Membran Plasma Spermatozoa Epididimis Kerbau Belang Pada Penambahan Maltosa Dalam Pengencer Andromed. Laporan Penelitian. Institut Pertanian Bogor. Bogor.

Hidayati N, Arifiantini Rl, Sajuthi D. 2015. Preservasi Semen Kambing Peranakan Etawa Dalam Pengencer Tris Dan Sitrat Kuning Telur Dengan Penambahan Sodium Dodecyl Sulphate. Jurnal Veteriner. 16(3):334-342

Husin N, Suteky T, Kususiyah. 2007. Uji Kualitas Semen Kambing Nubian Dan Peranakannya (Kambing Nubian X PE) Serta Kambing Boer Berdasarkan Lama Penyimpanan. Jurnal Sains Peternakan Indonesia. 2(2):57-61

Imansih L. 2014. Pemanfaatan Ekstrak Buah Naga (Hyocereus undatus) Pada Pengencer Berbasis CEP-1 Untuk Pengawaetan Spermatozoa Kambing Peranakan Boer Pada Suhu $32^{\circ} \mathrm{C}$. Publikasi Ilmiah. Fakultas Peternakan. Universitas Mataram.
Kostaman T, Suatama IK. 2006. Studi motilitas dan daya hidup spermatozoa kambing boer pada pengencer tris-sitratfruktose. Jurnal Sains Veteriner. 24(1):58-64.

Kusumawati ED, Leondro H, Krisnaningsih ATN, Susilawati T, Isnaini N, Widhad R. 2016. Pengaruh Suhu Dan Lama Simpan Semen Segar Terhadap Motilitas Dan Abnormalitas Spermatozoa Kambing Peranakan Etawa (PE). Seminar Nasional Hasil Penelitian. p:199-208

Munawarah. 2014. Pemanfaatan Ekstrak Buah Naga (Hylocereus undatus) Untuk Pengawetan Spermatozoa Kambing Peranakan Boer Pada Suhu $5^{\circ}$ C. Publikasi Ilmiah. Universitas Mataram.

Noor MI, Yufita EY, Zulfalina. 2016. Identifikasi Kandungan Ekstrak Kulit Buah Naga Merah Menggunakan Fourier Transform Infrared (FTIR) Dan Phytochemistry. Journal of Aceh Physics Society. 5(1):14-16.

Nurliyana R., Zahir IS, Suleiman KM, Aisyah MR, Rahim KK. 2010. Antioxidant Study Of Pulpl And Peels of Dragon Fruids:A Comparave Study. International Food Research Journal. 17(1):367-375

Putri NKM, Gunawan IWG, Suarsa IWG. 2015. Aktivitas Antioksidan Antosianin Dalam Ekstrak Etanol Kulit Buah Naga Super Merah (Hylocereus costaricensis) dan Analisa Kadar Totalnya. Jurnal Kimia. 9(2):243-251

Rizal M, Herdis M. 2010. Peranan Antioksidan Dalam Meningkatkan Kulaitas Semen Beku. Jurnal Wartazoa. 20(3):139-146

Sayuti K, Rina Y. 2015. Antioksidan, Alami Dan Sintetik. Padang: Andalas University Press; p.67-68

Susilawati T. 2011. Tingkat Keberhasilan Inseminasi Buatan Dengan Kualitas Dan Deposisi Semen Yang Berbeda Pada Sapi Peranakan Ongole. Jurnal Ternak Tropika. 12(2):15-24

Tophianong TC, Agung B, Maha NE. 2014. Tinjauan Hasil Inseminasi Buatan Berdasarkan Anestrus Pasca Inseminasi Pada Peternakan Rakyat Sapi Bali Di Kabupaten Sikka Nusa Tenggara Timur. Jurnal Sain Veteriner. 32(1):46-54

Utomo S. 2013. Pengaruh Perbedaaan Ketinggian Tempat Terhadap Capaian Hasil Inseminasi Buatan Pada Kambing Peranakan Etawa. Jurnal Sains Peternakan. 11(1):34-42

Wulandari R, Budiyanto MAK, Waluyo L. 2016. The Influence of Various Concentration of Red Roses (Rosa damascena mill) Flower Extract To Anthocyanin Color Stability Jelly As Biology Learning Source. Jurnal Pendidikan Biologi Indonesia. 2(1):4856 